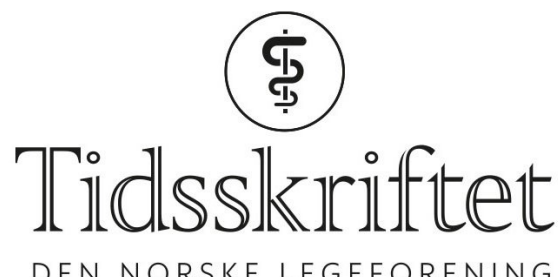

DEN NORSKE LEGEFORENING

\title{
Fiskeren, hvalen og vesten
}

TIDLIGERE I TIDSSKRIFTET

JULIE DIDRIKSEN

Tidsskriftet

«Det er en hvit hval, sier jeg,» fortsatte Akab og slengte fra seg mokkerten, «en hvit hval. Stirr øynene ut av hodet etter ham, karer, hold skarp utkikk etter hvitt vann; hvis dere ser så mye som en boble, så syng ut.» Det er ikke godt å si om det var Moby Dick fiskeren i den følgende artikkelen fra Tidsskriftet nr. 16/1950 fikk øye på, men det gikk galt da kanonen ble avfyrt. Da er det kjekt å ha en kreativ lege om bord (Tidsskr Nor Lægeforen 1950; 70: 541).

\section{Bandasjevest til behandling av ribbensfracturer.}

Som læge på Fl. K. «Thorshammer», sesongen 1947-48, fikk jeg til behandling et alvorlig tilfelle av ribbensfractur.

En skytter fikk et kraftig tilbakeslag av kanonskjeftet og pådro seg fractur av VIII. og IX. costa på høyre side. Han var helt arbeidsudyktig på grunn av skaden. Jeg la på den vanlige sirkulære plasterbandasje, og lot pasienten forsøke å arbeide. Dagen etter kom han imidlertid tilbake og ba meg om å finne på en bedre behandlingsmetode. Hver tapt arbeidsdag betydde for ham selv og selskapet mange penger. Jeg kom da på den tanke å lage en vest med regulerbar snøring i ryggen. Diakonen ombord sydde vesten av ubleket lerret og etter mål. Da pasienten fikk vesten på, ble situasjonen totalt forandret. Han ble smertefri og igjen lysten på kamp med hvalen. Vesten hadde han på i tre uker og var ikke en dag arbeidsudyktig. 


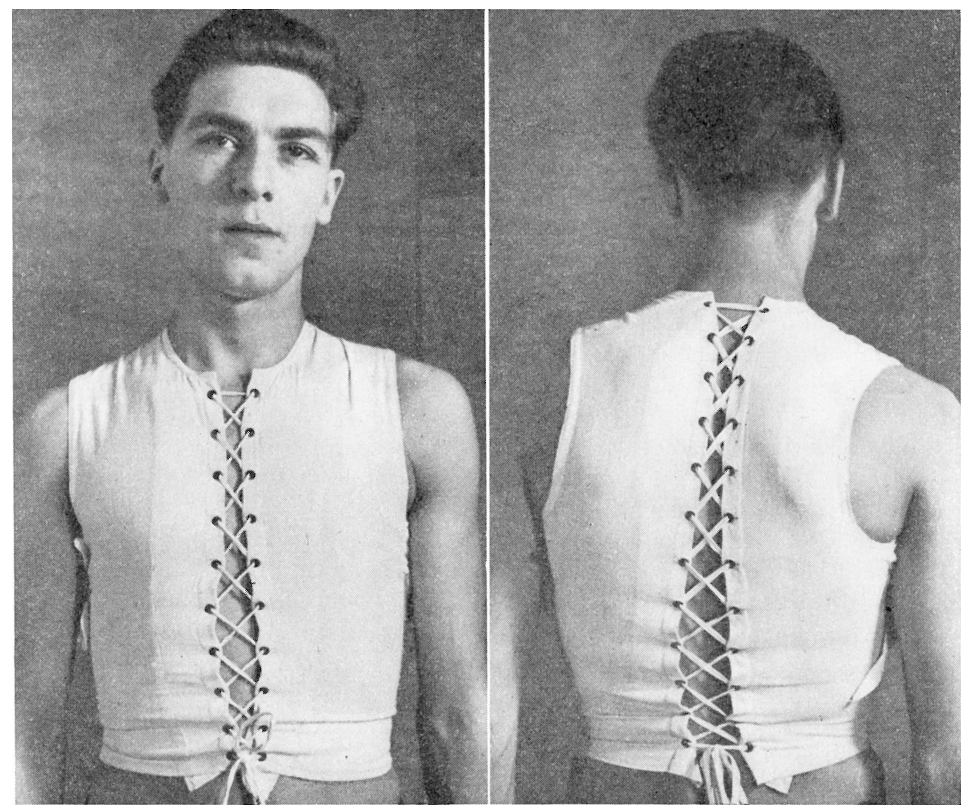

I løpet av de siste to år er vesten blitt en del forandret og forhåpentlig forbedret.

Som illustrasjonen viser består bandasjevesten av to stykker, en for hver halvpart av brystkassen, som forbindes med hverandre ved regulerbare snøringer i rygg- og brystparti. I armhullene er det laget en ca. $5 \mathrm{~cm}$ lang splitt med snøring for å kunne regulere armvidden. Den regulerbare ryggsnøring er laget, vesentlig for tilpasning av pasientens størrelse.

Ved påsetting er vesten snørt i ryggen, men reguleres etter pasientens størrelse. Man begynner snøringen foran fra halsgropen, og snører løst til i høyde med papillen. Deretter snører man, under ekspirasjon, så fast at pasienten føler seg smertefri. Pasienten kan også til nød greie å utføre påsetningen selv.

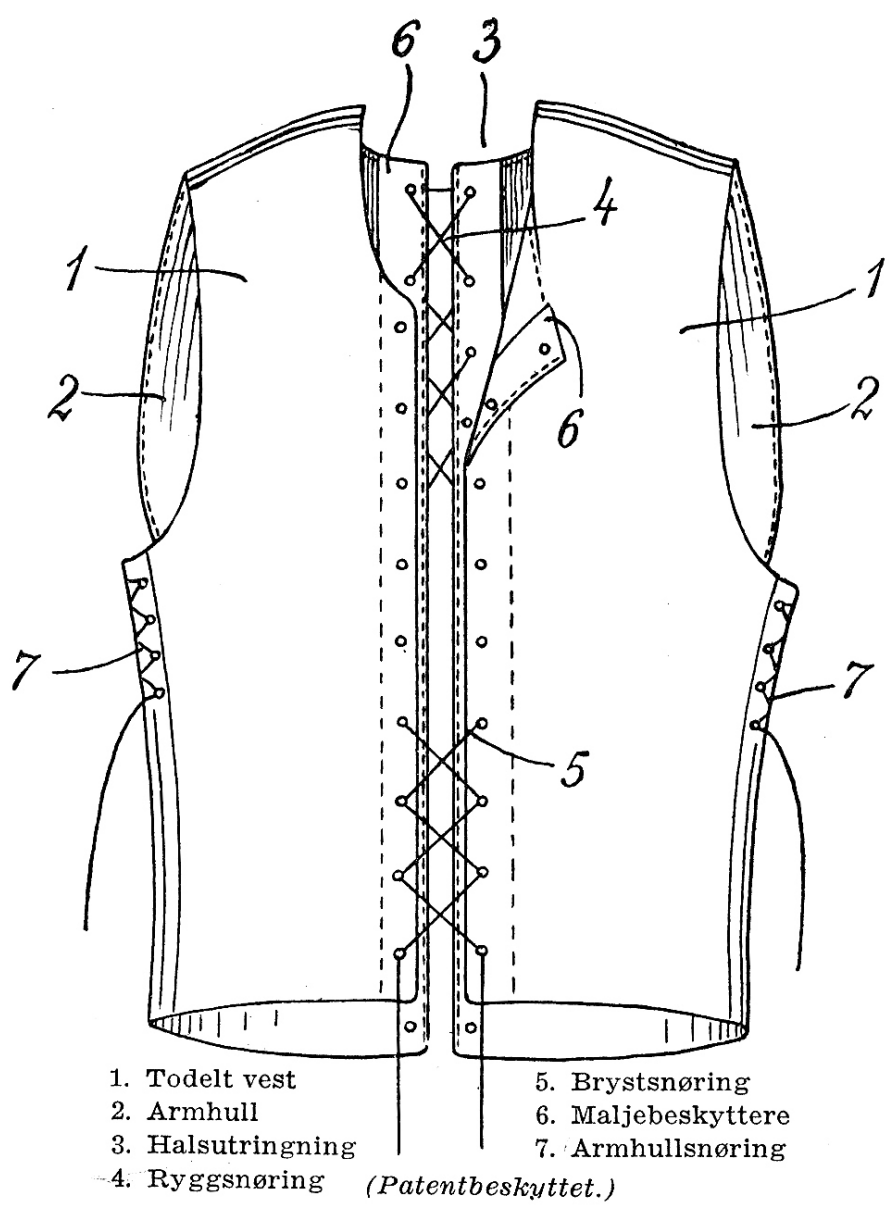

Som omtalt av H.K. S a n d b e r g i siste nr. av Tidsskriftet, kommer man også til målet ved 
hjelp av andre behandlingsmetoder. Selv plasterbehandling kan hos gracile pasienter hvor symptomene ikke er særlig uttalte, føre fram. Brede lerretsbind gir god støtte, på Oslo komm. lægevakt brukes ca. $12 \mathrm{~cm}$ brede flanellsbind. Men ulempene er at de glir, særlig hos pasienter med velutviklet adipositas, selv om man forsøker å holde bindet oppe ved hjelp av skulderstropper. Jeg har nå i to år benyttet bandasjevesten til pasienter, hvor plasterbehandling ville ha vært til besvær og plage. De relativt få jeg har behandlet, også pasienter som tidligere har vært utsatt for plasterbehandling, har alle uttalt at vesten har vært behagelig å bruke og at den har ytt god hjelp.

RolfReiler.

Publisert: 6. desember 2018. Tidsskr Nor Legeforen. DOI: 10.4045/tidsskr.18.o833

(C) Tidsskrift for Den norske legeforening 2020. Lastet ned fra tidsskriftet.no 